\title{
Management Knowledge and Standard Operating Systems in Formulating Company Development Strategies
}

\author{
Emmy Ermawati \\ Department of Accounting, STIE Widya Gama Lumajang \\ Email: emmy.ermawati01@gmail.com
}

\section{A R T ICLE INFO}

Date of entry:

22 April 2020

Revision Date:

8 May 2020

Date Received:

11 May 2020

\begin{abstract}
A B S T R A C T
This study aims to determine the importance of management science and company operational standardization that is applied, to know a good and correct company development strategy in accordance with operational standards of company development strategy at UD. AQMARINA. This type of research is descriptive research with a qualitative approach where the data obtained from a UD. AQMARINA in the form of observation, interviews and literature study. The data used is primary data, where the data is processed from interview data of company owners and publications. The results of this study state that the importance of management knowledge and company operational standards for strategy development is very necessary, this is because the process of organizing something is done by a group of people organization to achieve these goals by working together to utilize the available resources by developing strategies. The standardization of company operations that is applied to this company is very standard, therefore it is necessary to have guidelines on the company's operational system so that it can run the company optimally. A good and correct company development strategy according to operational standards, this is done to get quality human resources with skills, work abilities, and job loyalty to a company or organization. The company's development strategy is not only skill development but also products produced in the form of product variants which are of course creative and innovative.
\end{abstract}

Keywords: Management Knowledge, Company Operational Standards, Company Development Strategy

Cite this as: Ermawati, E. (2020). Management Knowledge and Standard Operating Systems in Formulating Company Development Strategies. Jurnal Ilmu Manajemen Advantage. 4(1), 15-23. https://doi.org/10.30741/adv.v4i1.602

\section{INTRODUCTION}

Management according to experts is an art in science such as planning, identifying, organizing, and monitoring. Management is a science that is quickly understood. Management is a form of cooperation between members to achieve a goal. Management is the art of implementing and organizing within the organization, this management also teaches in an organization the process of achieving goals in an organization by requiring cooperation between individuals with well- 
established communication. Management is indispensable for the progress of a company because by managing the course of the company according to what is planned, both short and long term, the company's goals will be achieved immediately.

According to Rifai (2016) Manaagement is a journey that is used to achieve and determine targets that have been allocated by utilizing human resources and other sources. The management of a trip that is quite unique consists of scheduling, grouping, moving and monitoring actions. Apart from that, management will not run optimally if one of these things is not done or functioned optimally. So management can be said as a coordinated unit of various human resources and other resources and cannot stand alone without the coordination, scheduling and arrangement of the managers of a company.

Managing a company with a complex scope of work and diverse human resources is not easy. In order to achieve the company's vision and mission properly, all existing components must be maximized. One thing that must be done is by making Standard Operating Procedures (SOPs). This Standard Operating Procedure (SOP) is not just a rule, but the place for a Standard Operating Procedure (SOP) in a company is very helpful in the company's growth process itself. Standard Operating Procedures (SOP) even have an effect on advancing the company. This is if the Standard Operating Procedure (SOP) is not properly implemented, it will have an impact on the performance of human resources at the company to decline and in the end the quality of production will also decline. This also affects the success of a company, the ups and downs of a company are not only supported by the country's economy but also on the importance of the management of a company and the strategies it uses.

Companies that have complex or repetitive jobs will need clearer rules. This regulation is made of course which aims to tell in detail how all Human Resources (HR) in the company act in accordance with predetermined standards according to their main duties and functions. So that later there will be an orderly and effective work flow. With the existence of Standard Operating Procedures (SOP), of course, it can ease the work of all existing Human Resources (HR). With new employees, they will get to know them more quickly because there are already clear regulatory standards. It is very important Standard Operating Procedure (SOP) for both large and small companies because the rules relating to main duties and functions are regulated in it. The continuity of these employees really determines the rhythm of the company, good performance must have a positive effect on the company in general.

From the management side it will also easily carry out control and supervision of the overall work nets. However, it is easier to get the odd thing out if you know something went wrong. So how to deal with all of this by quickly carrying out the process of making suggestions and decisions. In addition, there are still many objectives for Standard Operating Procedures (SOPs) that can make the effectiveness of all company lines, some of which are: a) One of the parameters in assessing the quality of company services, b) To maintain consistent production quality and performance c) To prevent work accidents, d) To maintain the flow and corridor of each employee's duties.

Apart from having quite clear objectives, the existence of Standard Operating Procedures (SOPs) also has functions for various things, such as making the duties of all existing employees run smoothly, Standard Operating Procedures (SOPs) can be used as a legal basis if things happen outside the company's corridors. , can be used as a tool to check existing problems, and much more.

Strategic management helps the company in dealing with changes that the company is not ready to anticipate in its current conditions. The global economic crisis is a major obstacle that is often ignored by companies in an improving economic situation and obtaining maximum benefits, so when the situation worsens, the role of strategic management becomes very important and is needed by the company. When the company is on the verge of a big problem, it will be too late to 
implement a strategic management. This is due to time we cannot allocate beforehand and a situation that we cannot predict. Strategic management can provide an organization's support in combining, analyzing, and organizing information.

Strategic management has short-term goals as an organizational pillar that must be reached to achieve long-term goals. Long-term goals, annual goals that must be measurable, quantitative, challenging, realistic, consistent, and prioritized. They must be defined at the company, divisional, and functional levels of the large organization. Annual objectives should be stated in terms of management, marketing, finance / accounting, production / operations, research and growth, and information systems. In terms of annual goals required for each long-term goal. Long-term goals are very important in strategy formulation, while annual goals are especially important in the implementation strategy. The annual objective is a basic objective for distributing resources. Policy is the means of annual goals that must be achieved. Policies include guidelines, regulations, procedures that are established to conducive efforts to achieve stated goals. From here it is important that there is a strategy made by the company to support short-term and long-term goals. Changes in one component or model in the company may require changes in one of the other components. For example, economic change can represent a great opportunity and require changes in the long term and strategic objectives, annual failure to achieve objectives can require changes in policy or major rivals of strategic change may require a strong change in mission. Therefore, strategy formulation, implementation, and evaluation of activities must be carried out continuously, not only at the end of the year. The strategic management process never really ends. The application of the strategic management process is usually more formal and larger in large organizations and vice versa. Companies that have many divisions, products, markets, and technology also tends to be more formal in the implementation of strategic management concepts. The next benefit of strategic management is the main advantage of strategic management: Proactive in growing the company's future in implementing actions to formulate better strategic management (systematic, logical, rational approach) from the financial side: advancing productivity Increasing sales Increasing profitability. Non-Financial Benefits: Advancing employee productivity and understanding of competitor strategies from the results of this study reveal that organizations that use strategic management concepts are more profitable and successful than people who do not use company operational standards and do not use appropriate company strategies.

\section{METHODS}

This type of research used by researchers is descriptive qualitative. According to Sugiyono (2016: 9) qualitative research methods are research methods used to examine the conditions of natural objects where the researcher is the key instrument.Thus the meaning or definition of qualitative research is research used to examine the condition of the object. It is only natural that the researcher is the key instrument. The approach used in this study is a qualitative approach, qualitative research, namely, research that does not use calculations or explain it by scientific research that emphasizes the natural character of the data source. This type of research is a case study, because this research uses a qualitative approach and includes case study research so the results of this research are descriptive analysis, namely how the existing operational system in the soy sauce company UD. AQMARINA which is already running well and wants to be developed to be more and more advanced and to increase the performance and turnover of the company that is being raised.

The object selected in this study is the extent to which the importance of management knowledge and operational standards of the company system in formulating the company development strategy of UD. AQMARINA. Research must have a research object so that it makes the course of research more focused on predetermined goals. Basically, an object is something that will or will be examined in a research activity. The object of research is an object that explains what the data is 
or who is the object of research, also where and when the research was carried out, it can also be added with other things if deemed necessary. While other opinions of the object of research are defined as an attribute or nature or value of a person.

Based on the type of data obtained at the company by formulating a company development strategy UD. AQMARINA, the data management and data analysis technique used is a qualitative descriptive method, that is, before the data is analyzed, the collected data must meet the validity of the data in accordance with the research. The data technique used in this study began by examining all available data from various sources, namely interviews, field observations, official documents, and several photos of activities. This research approach uses interviews to all employees and company leaders about how important management knowledge and operational standards are in the company's systems in formulating a soy sauce company development strategy (UD. AQMARINA).

Data Collection Techniques To obtain the data needed in this study the researchers used the following methods: a. Observation. Observation is a technique or approach to obtain primary data by directly observing the data object. b. Interview. Interviews are two-way communication to get data from respondents. Researchers held direct questions and answers, both formally and informally, with the parties involved in the issues to be discussed in the research writing, namely regarding the application of accounting in company financial records. c. Literature review. Literature study is by visiting the library and looking for literature books that match the issues raised, and the information obtained will then be used to solve the problem.

At this stage, data collection was carried out regarding information on the UD AQMARINA soy sauce company which would be used as the object of research to find out how important the management knowledge and operational standards of the company system were in formulating the UD soy sauce company development strategy. AQMARINA. Collection of UD data. Aqmarina is as follows: 1. Researchers collected data through observation activities and direct observations in the field as well as taking documentation, interviews and discussions with UD AQMARINA employees and owners. Data Analysis Data analysis was carried out in a descriptive qualitative manner, namely the recording process to describe the state of the object under study based on the facts and conditions that occurred in the field. 2. Mapping data on the production process and supply of soy sauce companies including suppliers, production and consumers. Also identified various problems that arise in soy sauce production. Furthermore, a strategy analysis is carried out by the company through the stages in accordance with the literature study. The hope is in accordance with the objectives of this study. 3. The time used during the research is 30 days during company working hours to make it more effective and efficient in retrieval of information.

\section{RESULTS AND DISCUSSION}

Soy sauce is a food ingredient that has a soy base ingredient. With the rapid advancement of technology, the soybeans used must be of good quality, including using black soybeans which are native to Indonesia. Soy sauce is very popular in Indonesia because it is affordable in terms of price but fulfills sufficient nutritional value. This is what makes the soy sauce company UD. AQMARINA produces soy sauce. Apart from the abundance of raw materials in Lumajang district, the price of the ingredients is very affordable. The soy sauce company UD. AQMARINA is a subsidiary company of UD.SHABRINA which was successful in developing processed snack products by the typical Lumajang Regency. The business occupied by UD. SHABRINA includes fila bread, banana chips and herbal concoctions which are sold in bottles. This company was started by a husband and wife, namely Drs Aminuddin and Drs. Mahindar who is the owner of this company. This company is located in Lumajang Regency, which is on Jln Setail 20 Lumajnag. At first they did marketing in the city by opening a souvenir shop at home and gradually began to develop marketing in supermarket stores in Lumajang district. By entering into an MOU with 
several agencies, this is an opportunity in its development. At first he participated in the auction market at Bank Jatim Surabaya once a month. Even this product has also expanded outside the city of Lumajang, namely in several large supermarkets in the cities of Jember and Probolinggo. Being one of the products sold in large supermarkets like Carefour is a matter of pride for the owner.

In starting this soy sauce company, many ups and downs experienced, of course, made it a good experience. The grief is that doing this soy sauce business does not immediately get a market, but for about two years the market has only existed. Previously they were looking for and looking for markets. Starting from the capital of the smallest stove and frying pan, until now, we have used the biggest stove and frying pan. Including the use of technology, too. From my friends' experience, the first time I tried the tube it took a week to run out of three pumps. Finally, there is a suggestion from a friend who uses a disposable electric pump that can be used for three stoves. In the early days of production, 12 employees were recruited, but everything didn't go according to plan. Understandable because this is the first time. Furthermore, there is a selection process because it is considered that they are recruiting too many employees and are considered inefficient, so from the current needs selection only 8 people are left. For 2.5 years they can only be released to operate this soy sauce company. But even then they don't work every day, only twice a week.

Funding used in the soy sauce company UD. AQMARINA is derived from its own capital and there are several grants obtained from district government development programs. It can be said that this company is superior in several fields of production but is not maximal in knowledge of the importance of management science and its operational strategy. It is unfortunate if the creative ideas of the nation's children by maximizing the production in their surroundings are to make a product that has a high selling value. The lack of knowledge about management makes this soy sauce business unable to run its business optimally. The need for all incomplete materials and the performance of employees who still have to wait for command from the owner in each implementation. Not all employees understand their respective main duties and functions so that they do not work for each other to wait for orders from one another. Minimal equipment requires consultation and innovation to make work easier. This is where management knowledge and strategy formulation are needed so that company operations can run smoothly.

After we made observations and interviews with employees and company owners from several lists of questions that we made and referred to the research objectives and the problems raised in this study. Then it can be interpreted as follows: How Important is Management Science and Company Operational Standards for Strategy Development. It is very important management knowledge and company operational standards for technology development. The definition of management is a process to regulate something that is done by a group of people organization to achieve the goals of the organization by working together to make the most of the available resources. Some of the main reasons about the importance of the role of management strategy for the soy sauce company UD. AQMARINA includes: a) Clarify the long-term goals to be achieved. b) Make it easier for companies to adapt to new policies. c) Make a company or organization more active. d) Identify companies that have a comparative advantage which makes them even more risky. e) It is very difficult to dynamize changes in old employees. f) The implementation stage will be better if it involves all employees so that it becomes motivation for employees. g) Making a strategy will enhance the ability of the company or organization to prevent problems from arising in the future.

From the main reasons explained on the importance of the role of management strategy for a company, more specifically the soy sauce company UD. AQMARINA is an attestation of long term goals that so far has not been owned by UD. AQMARINA. In the end, when several policies changed, employees experienced difficulties in making decisions and organizing. Because after all the decision returned to the owner of the company. Being an active company, UD AQMARINA had a very difficult time because after all the decision still depends on the policy of the leader. If every company already knows how to properly manage and what strategies are used, they can 
certainly measure the performance of each employee. So if employees do not match their expertise, they can be replaced immediately because if they are left alone, the work of the soy sauce company cannot be maximized. When the karwayan used is in accordance with the expertise they have, it is even easier to divide it according to the employees' main tasks and functions which will make the work more efficient. Competent employees will provide many solutions for the company to be more advanced. If the Standard Operating Procedure (SOP) has been implemented properly, the company's goals will be achieved soon.

Standardization of Company Operations Applied to the Company. Knowledge of management knowledge owned by UD. AQMARINA is very standardized so that it cannot streamline time, effort and costs so it needs training or at least information on knowledge about proper management and operational standards in a company. Operational standardization in the company, this is very necessary to be determined in order to assist in managing a company with a complex scope and diverse human resources is not easy. All the existing elements must be maximized properly so that what is the company's vision and mission can be achieved properly. One way to do this is to create and implement standardized company operations. With the implementation of this company standardization, the company is able to act in accordance with existing standards and its main duties and functions. So that later an orderly and effective work flow will emerge. And of course, the existence of operational standardization can facilitate the work of all existing human resources. If there are new employees, they will also adapt quickly because there are clear regulatory standards. From the management side, it will also be easy to control and supervise the overall workflow. It will be easy to get things that are not fair if you encounter an error. So that it will quickly make decisions and solutions to overcome them. This operational standardization can also help discipline all levels of the company in a more positive direction to be more responsible in a job. This operational standardization can also detect the obstacles that are being or will be experienced by employees so that the company can anticipate unexpected things in running the company, including the obstacles that are being or will be experienced by employees. If the obstacles are known, the company can find a way out in solving the problems it faces without disturbing the running of the company.

Good and Correct Company Development Strategy According to Operational Standards. Standard company development at UD. AQMARINA is very limited, because in this company it prioritizes the attitude of descent from what was inherited by UD. SHABRINA before. They rely on all decisions just waiting for what is conveyed by the family or from the previous leadership. No new innovations are conveyed for the smooth running of a company. This company development strategy is carried out to carry out qualified personalities with skills, work abilities, and job loyalty to a company or organization. The company's development strategy is not only skill development but there are many ways to develop it. There are several strategies that can be studied by companies in developing and finding the human resources needed, including training, coaching, system changes, opportunities and rewards. With the existence of a good and correct company development strategy, it can carry out processing of its products to innovate the product to make it different and look more attractive than other products. In order to compete with other products. With this strategy it can also provide affordable and competitive prices, as well as, provide maximum service to consumers. With the creation of a good and correct company development strategy, it can establish a harmonious relationship with internal and external parties of the company. In the company development level which consists of the production level, the commercial level and the corporate level. With the existence of a good and correct company development strategy, it can carry out processing of its products to innovate the product to make it different and look more attractive than other products. In order to compete with other products. With this strategy it can also provide affordable and competitive prices, as well as, provide maximum service to consumers. With the creation of a good and correct company development strategy, it can establish a harmonious relationship with internal and external parties of the company. In the company development level which consists of the production level, the commercial level and the corporate level. With the existence of a good and correct company 
development strategy, it can carry out processing of its products to innovate the product to make it different and look more attractive than other products. In order to compete with other products. With this strategy it can also provide affordable and competitive prices, as well as, provide maximum service to consumers. With the creation of a good and correct company development strategy, it can establish a harmonious relationship with internal and external parties of the company. In the company development level which consists of the production level, the commercial level and the corporate level. In order to compete with other products. With this strategy it can also provide affordable and competitive prices, as well as, provide maximum service to consumers. With the creation of a good and correct company development strategy, it can establish a harmonious relationship with internal and external parties of the company. In the company development level which consists of the production level, the commercial level and the corporate level. In order to compete with other products. With this strategy it can also provide affordable and competitive prices, as well as, provide maximum service to consumers. With the creation of a good and correct company development strategy, it can establish a harmonious relationship with internal and external parties of the company. In the company development level which consists of the production level, the commercial level and the corporate level.

The solution expected for UD. AQMARINA present and future. Solution is something that must be done to change a situation for the better. Why is a solution needed, because the problems faced will be resolved with a solution that is carried out either gradually or directly. Not all companies are willing to receive positive feedback. However, if we convey it correctly and clearly, the company will certainly accept the progress of the company. After we observe the results of interviews with all employees and owners of the company UD. AQMARINA, it is necessary to have several solutions that must be implemented so that this company can develop including:

Increase promotion. Promotion is a medium to provide information to the public that we have soy sauce products at affordable prices and premium quality, this needs to be done seriously both mass media and social media. Social media is currently the best promotional media because it is cheap but can be reached by people at home and abroad. It doesn't have to be set at a certain time, but social media can be reached by all groups, wherever and whenever the information is accessed.

Correctly identify who our competitors are. When making a product, we must understand who our competitors are, who our consumers are, so we know who our market share will be which we will target in marketing this soy sauce product. Be vigilant with competitors, so you have to think creatively and innovatively so that there is still a difference between our products and those of competitors.

Extending the network we have. Back again to promos, because with intense promotions and our products are accepted by the wider community, business relations who want to get acquainted with us will definitely want to accept the products we produce. Some may even be interested in sharing the results can be discussed in accordance with clauses that must be obeyed. $d$. Increase the resource expertise possessed by the company. Employee recruitment that we carry out must understand how our products are, how to process them so that production can be maximized because employees know how to operate machines properly and correctly and on time.

The main priority is the best service for consumers or buyers. The buyer is king, why is that because the quality of service is benchmarked against this too. When the service is good and satisfying, consumers will definitely recommend it to family and friends so that they want to give our products according to the experience they have. Likewise, if the opposite is true, consumers are lazy to buy our products back.

More creative and innovative about the products we produce. Creative and innovative really need to be considered so that our products have more value than those of our competitors. Creative and innovative product variants and packaging will be loved by consumers so that whenever they need it, they will definitely come back to us. 
Streamline company operating costs. When the employees we recruit are competent in their field, they will automatically be able to work optimally. Counting the raw materials used is not excessive because there are measures that are adhered to.Measuring when we bring in raw materials also needs employees to obey for a company operation because with this the raw materials we bring will pile up uncontrollably and eventually rot is wasted. Not a few companies have a large area of land, without any control to bring in the right raw materials, they can pile up on one land and disrupt company activities.

Investation. It is mandatory for companies to invest, investment can be in the form of money or machines. Why is that, because the use of machines every day is increasing continuouslyAbandon its function has decreased slightly and this requires maintenance that is carried out according to the company's schedule on a regular basis every month. When the maintenance is always carried out, the engine failure will be immediately handled without having to hinder the running of the company. Investment is very important for the company for the development of the company in the future.

Manage finances as best as possible. This is what we will later use for company operations and to find out each production time what percentage is obtained. Is the maximum profit or not. When the profit is not maximal, we can evaluate the constraints experienced by the company so that the production capacity is not maximal. After that, we can find solutions to solve problems experienced by our company.

The need to attend training courses to motivate employees and company owners. After observations and interviews conducted about the lack of management knowledge and strategy formulation, it is very influential for the sustainability of the company. Therefore, UD. AQMARINA needs to conduct a comparative study and attend several trainings tailored to the fields needed by the company. Why is there a need for a comparative study and review of some literature because with this, company benchmarks can be known whether or not it is progressing and can motivate employees or owners to be more creative and innovative in developing the products produced

\section{CONCLUSION}

This research was conducted at the company UD. AQMARINA which after being examined by researchers by comparing how the company operates until it can formulate strategies that must be done in the company in order to increase the company's turnover. And the results state that the importance of management science and company operational standards for the development of technology used to facilitate production and improve employee and company performance. With strategic management, it is expected that the strategy can be properly managed so that it can be implemented to take and integrate all decisions and actions within the company. Standardization of operations in the company is very necessary to be implemented so that it is not easy to assist in managing a company with a complex scope and diverse human resources. All the existing elements must be maximized properly so that what is the company's vision and mission can be achieved properly. One way to do this is to create and implement standardized company operations. With the implementation of this company standardization, the company is able to act in accordance with existing standards. So that later an orderly and effective work flow will emerge. This company development strategy is carried out to carry out qualified personalities with skills, work abilities, and job loyalty to a company or organization. The company's development strategy is not only skill development but there are many ways to develop it. There are several strategies that can be studied by companies in developing and finding the human resources needed, including training, coaching, system changes, opportunities and rewards. 
For the company, it is better if the owner regularly reviews and conducts comparative studies with other companies to find out how far the company has progressed. The function of the comparative study is to imitate the strategies that must be done so that the company can progress and develop. And then the company can formulate what strategies the company should use to face competition and make the company exist and have a wider market share, especially supported by the maximum possible promotion and the development of creative and innovative ideas.

For other researchers, this research topic should be able to review using different populations, different samples and more than one company case in order to obtain other better findings and useful for developing knowledge. This research can be used as a similar reference and can be used as a reference for studies in other objects with different research models.

\section{REFERENCE}

Daryanto. (2012). Production Management. PT Sarana Tutorial Nurani Sejahtera. One Nusa Studio.

North Sulawesi Provincial Forestry Service. (2014). Forestry Profile of North Sulawesi Province (Pdf).

Fahmi. (2012). Production and Operations Management. Publisher: Alfabeta, Bandung. Faculty of Agriculture, Bogor Agricultural University.

Grenda Bakery Lianli Bahu Malalayang (Thesis). Sam Ratulangi University, Manado Agriculture Faculty

Haming, M. and Nurnajamuddin, M. (2012). Modern Production Management (Manufacturing and Service Operations). Second Edition First Printing. Publisher: PT Bumi Aksara. Jakarta.

Handoko. (2000). Basics of Production and Operations Management. Publisher: BPFE Yogyakarta.

Helena. (2005). Analysis of the Procurement and Inventory Control System for Traditional Herbal Raw Materials at PT.X Bogor. Agribusiness Management Study Program

Julianus, K and Irawan, A. (2011). Study on the Diversity of Cempaka Species Based on Morphological Characteristics in North Sulawesi (Research Journal), Manado Forestry Research Center.

Julianus, K and Mahfudz. (2011). Prospects for Cempaka Development in North Sulawesi (Scientific Journal). Forestry Research and Development Agency, Manado Forestry Research Institute.

Kurniawan.W, (2008). Analysis of the Control of Raw Material Inventory in Soy Sauce Company, Triangular Majalengka. Agribusiness Management Extension Undergraduate Program, Faculty of Agriculture, Bogor Agricultural University.

Nasutioon, A. H. (2003). Planning and Production Control.First Edition. Surabaya: For Widya.

Prawirosentono, S. (2007). Operations Management (operations management) analysis and case studies. Fourth edition, first printing. Earth Literacy: Jakarta.

Prihasdi, R. D. (2012). Efficiency of the Economical Order Quantity (EOQ) Method in Making Decisions on Purchasing Raw Materials and Their Effects on Total Purchasing Costs at PT. Amitex (Amanah Mitra Industri) Buaran, Pekalongan Regency (Thesis), Faculty of Economics and Business, Diponegoro University, Semarang.

Ruauw, E. (2011). Control of raw material inventory (Example of control in the business of Grenda Bakery Lianli (Journal). Manado.

Sitorus, O. R. (2009). Types and prices of commercial timber and processed wood products in the Panglong secondary wood industry in Medan (Thesis). Department of Forestry, University of North Sumatra, Faculty of Agriculture, Medan.

Sutrisno. (2001). Financial Management. Yogyakarta: Econisia 